\title{
Characterization of Carbonic Anhydrase Isozyme Specific Inhibition by Sulfamated 2-Ethylestra Compounds
}

\author{
Katherine H. Sippel ${ }^{1, *}$, Andre Stander ${ }^{2}$, Chingkuang $\mathrm{Tu}^{3}$, Balasubramanian Venkatakrishnan ${ }^{1}$, Arthur H. \\ Robbins $^{1}$, Mavis Agbandje-McKenna ${ }^{1}$, Fourie Joubert ${ }^{4}$, Annie M. Joubert ${ }^{2}$, and Robert McKenna ${ }^{1}$ \\ Department of Biochemistry and Molecular Biology ${ }^{1}$ and Pharmacology and Therapeutics ${ }^{3}$, University of Florida, Gainesville, \\ Florida, United States of America 32610 and Department of Physiology ${ }^{2}$ and Bioinformatics and Computational Biology Unit, \\ Department of Biochemistry ${ }^{4}$, University of Pretoria, Pretoria, 0001, South Africa \\ ${ }^{*}$ Current Address: Department of Biochemistry, Baylor College of Medicine, Houston, TX, 77030
} Address correspondence to: Robert McKenna, Ph.D., P.O. Box 100245, Gainesville, FL 32610. Tel: (352) $392-5696$ Fax: (352) 392-3422; E-mail: rmckenna@ufl.edu

Running Title: Carbonic Anhydrase Isozyme Specific Inhibition by 2-Ethylestra Compounds

\begin{abstract}
Sulfamated 2-ethylestra compounds have demonstrated strong anticancer activity, high bioavailability and an ability to bypass liver metabolism by reversibly binding carbonic anhydrase (CA) II in erythrocytes. Another CA isoform, CA IX, is overexpressed in many cancers. The CA domain of CA IX is oriented extracellularly, which may permit targeting inhibitors to tumors. Presented here is the characterization of three 2-ethylestra compounds bound to both CA II and a CA IX mimic protein. Inhibition by ${ }^{18} \mathrm{O}$ exchange showed that compound $\mathbf{1 6}$ demonstrated an approximately 12-fold higher affinity for CA II over CA IX mimic. Structurally, compounds 15 and 16 showed alternate binding modes between CA II and CA IX mimic, apparently due to a water-mediated hydrogen bond to the isozyme-specific residue 67. Though the specificity was demonstrated for CA II over CA IX, this study reveals insights that may be key to developing isozyme specific CA inhibitors for novel anticancer therapies.
\end{abstract}

\section{Keywords}

carbonic anhydrase, isozyme specific, structure based drug design, 2-Ethylestra compounds, anti-cancer therapy, steroid sulfatase inhibitors 


\section{Introduction:}

In the early 1990s it was discovered that the naturally occurring estrogen metabolite, 2-methoxyestradiol, inhibited cell proliferation and angiogenesis independently from the estrogen receptor [1]. It is believed that the mechanism of action for this compound is through an interaction with the colchicine binding site of $\beta$-tubulin impairing microtubule remodeling, inducing metaphase arrest and apoptosis [1-7]. Clinical trials of 2methoxyestradiol as a cancer treatment were halted due to an extremely low plasma concentration in patients despite high dose administration indicating a lack of oral bioavailability and high susceptibility to clearance by liver enzymes [8].

Independently it was discovered that 2-substituted estrone sulfamates, a class of steroid sulfatase inhibitors were antiproliferative towards cancer cells [9-11]. The cytotoxic properties of the sulfamates were similar to those seen in 2-methoxyestradiol. Numerous studies have been employed to identify the structure-activity relationships associated with various derivatives of the 2-substituted estrone sulfamates. Among the most promising were 2-ethylestradiol3,17-O,O-bis-sulfamate (compound 14), 2-ethylestrone 3-O-sulfamate (compound 15), and 2-ethylestradiol 3-Osulfamate (compound 16) (Fig. 1)[12-14]. Compound $\mathbf{1 4}$ was shown to be a highly effective anti-proliferative agent in vitro with a mean $50 \%$ growth inhibition concentration $\left(\mathrm{GI}_{50}\right)$ of $0.018 \mu \mathrm{M}$ across the National Cancer Institute's (NCI) 60 cancer cell line panel and in vivo in both breast and prostate cancer xenografted mice [12, 14]. Compound $\mathbf{1 5}$ also proved to be an effective anti-proliferative with a mean $\mathrm{GI}_{50}$ of $0.014 \mu \mathrm{M}$ in the NCI panel. Compound $\mathbf{1 6}$ was shown to have anti-angiogenic properties, was characterized in vitro with a mean $\mathrm{GI}_{50}$ of $0.016 \mu \mathrm{M}$ in the $\mathrm{NCI}$ panel, and demonstrated high bioavailability and growth inhibition in vivo with estrogen receptor negative breast cancer xenografted mice [13]. The benefits of these sulfamated compounds lie in both their high oral bioavailability and their capacity to circumvent first pass liver metabolism by reversibly attaching to carbonic anhydrase II in red blood cells protecting it from clearance $[15,16]$.

Carbonic anhydrase (CA) is a zinc metalloenzyme that catalyzes the reversible interconversion of carbon dioxide and water into bicarbonate and a proton. There are fourteen CA isoforms expressed in humans serving a wide variety of functions including respiration, $\mathrm{pH}$ homeostasis, and fluid retention [17]. CA II is a cytoplasmic isozyme expressed ubiquitously across most cell types including erythrocytes where it is essential for respiration. CA IX is a membrane-bound CA normally only expressed in cells requiring high extracellular $\mathrm{pH}$ such as gastric epithelial cells [18]. However in many cancers this protein is overexpressed during solid tumor growth, contributing 
to the acidification of the microenvironment and leading to altered nutrient transport, disruption of cell contacts, and the exclusion of some chemotherapeutic drugs [19]. For these reasons CA IX is a promising target for anti-cancer therapy either through its inhibition or as a targeting mechanism for more cytotoxic drugs [20]. The difficulty lies in designing a drug that is specific for CA IX as compared to the CA II. The active sites between the CA isoforms are highly conserved. They both have a hydrophobic region for binding $\mathrm{CO}_{2}$ and a hydrophilic region for proton transport into the bulk solvent. There are only a few residues that differ making structure-based, isozyme-specific drug design challenging.

This study assesses the effectiveness of the sulfamated estra- compounds in the context of CA II, as a mechanism of liver metabolism bypass, and CA IX, as a means of targeting the anti-proliferative action of the compounds to cancer cells. Because CA IX is difficult to produce in sufficient quantities for either kinetics or crystallography, this study utilizes a CA IX mimic (a CA II active site double mutant A65S N67Q) characterized previously [21]. Comparisons between the CA IX mimic and the recently determined structure of wt CA IX are discussed [22]. Through X-ray crystallography and ${ }^{18} \mathrm{O}$ exchange between $\mathrm{CO}_{2}$ and water, inhibition by $\mathbf{1 4}, \mathbf{1 5}$, and $\mathbf{1 6}$ were characterized for both CA II and CA IX mimic. Characterization of $\mathbf{1 4}$ with CA II has been described previously [23]. Kinetics show that $\mathbf{1 6}$ has nearly 12 -fold higher affinity for CA II and crystallography indicates significant structural differences between CA II and CA IX mimic in complex with either $\mathbf{1 5}$ or 16. A possible mechanism for this isozyme specificity and the implications on further structure based drug design of CA inhibitors are discussed.

\section{Materials and Methods}

Compound Synthesis- All compounds were synthesized by iThemba Pharmaceuticals (Modderfontein, Gauteng, South Africa). Two-dimensional chemical structures and full names are described in Figure 1. A full accounting of the synthetic steps is provided in Supplemental Information.

Protein Expression and Purification- CA II and CA IX mimic were prepared as described previously [21, 24].

Oxygen-18 Exchange - Inhibition constants $\left(\mathrm{K}_{\mathrm{i}}\right)$ of all compounds were determined by measurement of the inhibition of the catalyzed exchange of ${ }^{18} \mathrm{O}$ between $\mathrm{CO}_{2}$ and water, measured by membrane-inlet mass spectrometry as reviewed elsewhere [25]. Experiments were performed at $25^{\circ} \mathrm{C}$ in $0.1 \mathrm{M}$ HEPES, pH7.4 and $10 \mathrm{mM}$ total 
carbonate concentration. Inhibitor concentrations ranged up to $8 \mu \mathrm{M}$ and the data were processed using the Henderson method for tight-binding inhibitors [26]. Experimental values can be found in Table 1.

Crystallization and Data Collection- Crystals of CA II and CA IX mimic complexed with the compounds were obtained by co-crystallization using the hanging drop vapor diffusion method [27]. Crystallization conditions are as follows: $5 \mu \mathrm{l}$ of $15 \mathrm{mg} \mathrm{ml}^{-1}$ of protein and $5 \mu \mathrm{l}$ of $1.4 \mathrm{M}$ sodium citrate, $100 \mathrm{mM}$ Tris- $\mathrm{Cl}$, and $7.5 \mathrm{mM}$ of compound were suspended over $1 \mathrm{ml}$ of $1.4 \mathrm{M}$ sodium citrate and $100 \mathrm{mM}$ Tris-Cl. The crystallization $\mathrm{pH}$ for compounds $\mathbf{1 5}$ and $\mathbf{1 6}$ was $\mathrm{pH} 8$ and for $\mathbf{1 4}$ was $\mathrm{pH}$ 9. Crystals were soaked for 10 seconds in a cryo-protectant solution of $0.9 \mathrm{M}$ sodium citrate, $100 \mathrm{mM}$ Tris-Cl pH 8, 20\% glycerol. Initial structure solutions of CA II with $\mathbf{1 5}$ and $\mathbf{1 6}$ did not give sufficient density for compound modeling. Additional crystals were soaked in a solution of $1 \mathrm{M}$ sodium citrate, 50 $\mathrm{mM}$ Tris-Cl, $\mathrm{pH} 8,20 \%$ glycerol and $10 \mathrm{mM}$ of the compound. The crystals were flash-cooled to $100 \mathrm{~K}$ in a gas nitrogen cryostream. Data was collected in house using a Rigaku RU-300 rotating copper anode generator $(\lambda=1.5418$ $\AA$ ) on a R-AXIS IV++ image plates. The crystal-to-detector distance was $80 \mathrm{~mm}$, with $1^{\circ}$ oscillation width and $300 \mathrm{~s}$ exposure times. The data was merged using HKL 2000 [28].

Structure Determination- All the crystal structures were determined by molecular replacement methods using wt CA II (PDB code 2ili)[29]. The initial rigid body, individual coordinate and atomic displacement parameter (ADP) refinement was performed in PHENIX.refine [30]. $\mathrm{F}_{\mathrm{o}}-\mathrm{F}_{\mathrm{c}}$ maps provided phase-unbiased electron density for the respective bound inhibitors (Supplemental Fig. 1). The PRODRG server was used to generate coordinates and restraints for inhibitor modeling [31]. Refinement continued with alternating rounds in PHENIX.refine and manual model building in COOT [30, 32]. Ordered solvent was added, as well as TLS refinement and riding hydrogens. Refinement of the structures continued until the $\mathrm{R}_{\text {cryst }}$ and $\mathrm{R}_{\text {free }}$ converged. The compound-enzyme interactions were determined using LIGPLOT [33]. The PDB IDs, data, refinement, and final model statistics for the five novel structures are given in Supplemental Table 1. Ligand-protein interactions are listed in Supplemental Table 2.

Energy Calculations- All binding energies were calculated using the PISA server [34]. The wt CA IX values were derived by least-squares superposition of chain A of CA IX (PDB ID 3iai) onto either CA II or CA IX mimic. The glycerol and acetazolamide from 3iai was removed and replaced by the superposed compound coordinates. $\Delta \mathrm{G}$ values in $\mathrm{kcal} / \mathrm{mol}$ are listed in Table 1. 


\section{Results}

Comparison Between wild-type CA IX and CA IX mimic. Recently the structure of wt CA IX in complex with acetazolamide (AZM) was determined [22]. This provides the opportunity to assess the usefulness of the CA II A65S N67Q mutant as a CA IX mimic. Structural superposition of the wt CA IX (PDB ID, 3iai) and the CA IX mimic (PDB ID 3dc3) both complexed with AZM reveals that the location and environment of the AZM to be similar (Figure 2A). The $\mathrm{Zn}^{2+}$ to N1 and two Thr 199 hydrogen bonds are conserved between the two structures and the distances are within $0.1 \AA$ of one another. The bonds to His 94 and water-mediated bond to Pro 201 are within $0.3 \AA$ of each other and the hydrophobic contacts with Val 121 and Leu 198 are nearly superimposable. However, there is a slight plane displacement $\left(\sim 10^{\circ}\right)$ in the AZM molecule between the wt and mimic structures. The difference between the two structures can be attributed to two distinctive features. The first is the presence of glycerol (GOL) in the wt structure. GOL binding appears to shift Gln 92 and Gln 67 away from the AZM molecule and orients His 64 and Ser 65 into an outward conformation relative to the $\mathrm{Zn}^{2+}$. The second issue is the amino acid at position 131. In CA IX this is a leucine, whereas in the mimic it is the CA II phenylalanine. The bulkier phenylalanine provides an additional hydrophobic contact to AZM that is not present in the native protein. This may account for the some of the discrepancy seen between mimic and wt inhibition values [21]. Though the $\mathrm{K}_{\mathrm{i}}$ of mimic are similar to wt CA IX, interactions involving hydrophobic contacts with the Phe 131 are likely to be an overestimation of the affinity.

Inhibition. Assays measuring the inhibition of ${ }^{18} \mathrm{O}$ exchange catalyzed by CA II and CA IX mimic were conducted on compounds 14, 15, and 16 (Table 1). It is of note that esterase inhibition assays of compound 14 were performed with CA II previously with an inhibition constant of $230 \pm 60 \mathrm{nM}$ [23]. However, this test measures the steady-state inhibition of the esterase activity of CA and the current studies measure inhibition of carbon dioxide interconversion with bicarbonate at chemical equilibrium. These very different methods yield somewhat different values of inhibition constants.

Assays using ${ }^{18} \mathrm{O}$ exchange were carried out to provide inhibition constants for analysis. Compound $\mathbf{1 4}$ produced very similar inhibition constants between CA II, $880 \pm 70 \mathrm{nM}$, and CA IX mimic, $680 \pm 40 \mathrm{nM}$. Compound 15 had $\mathrm{K}_{\mathrm{i}} \mathrm{s}$ of $440 \pm 50 \mathrm{nM}$ for CA II and $590 \pm 30$ for CA IX mimic, revealing a small $34 \%$ decrease in affinity. In contrast compound $\mathbf{1 6}$ showed the most distinctive isozyme specificity with a $\mathrm{K}_{\mathrm{i}}$ of $180 \pm 10 \mathrm{nM}$ for CA II and $2100 \pm 220 \mathrm{nM}$ for the CA IX mimic, a nearly 12-fold difference. 
Compound 14 Structural Comparisons. The structure of 14 in complex with CA II has been solved previously (PDB ID 2x7t) [23]. Of note, the previously solved structure did not to adhere to CA II naming convention that skips residue 126. For comparison purposes the numbering has been adjusted to conform to this standard ( $\mathrm{n}+1$ for all residues 126 and above). As observed previously the 17-O-sulfamate (D-ring) preferentially binds the $\mathrm{Zn}^{2+}$ over the 3-O-sulfamate. This may relate to an increase in conformational flexibility of the cyclopentane over the planar benzene ring attached to 3-O-sulfamate or as suggested in Cozier et. al. the 2-ethyl substitution may disfavor the 3$O$-sulfamate coordinating to the $\mathrm{Zn}^{2+}$ [23]. Between CA II and CA IX mimic the orientation of $\mathbf{1 4}$ in the active site is nearly superimposable (Figure 2B, C, D and Supplemental Figure 1A). Both are coordinated to the $\mathrm{Zn}^{2+}$ and have two hydrogen bonds to Thr 199, with values within $0.2 \AA$ of one another. They share hydrophobic contacts with Pro 202, Leu 198, Val 135, and Phe 131. Both have a weak interaction with His 94. There is also an alternate conformation of His 64 in CA IX mimic with the inward conformation forming a hydrophobic contact. The 3-Osulfamate is also seen in a dual conformation in CA IX mimic

Compound 15 Structural Comparisons. There is a significant difference in the $\mathrm{Zn}^{2+}$-bound $\mathbf{1 5}$ complexed to CA II as compared to CA IX mimic (Figure 2B, C, E). The structure in CA IX mimic showed a clearly defined, zincbound ligand that refined to an occupancy of $85 \%$ (Supplemental Figure 1C). Additionally another low occupancy (58\%) molecule of 15 was identified (Supplemental Figure 1D).

The density of $\mathbf{1 5}$ in CA II was less ordered. The experiment was repeated with $\mathbf{1 5}$ additionally added in the cryoprotectant, improving the density enough for modeling at an occupancy of $60 \%$ with alternate water positions coordinating with those observed in unbound CA II. Though the density is contoured at a low sigma, most of the molecule can be seen clearly in an averaged kick map contoured to $0.8 \sigma$ (Supplemental Figure 1B) [35]. There was also a GOL molecule located in the active site.

In the two structures the orientation of the sulfamate is similar, leading to similar distances in the $\mathrm{Zn}^{2+}$ coordination and the hydrogen bonds to Thr 199, His 96, and His 119. The main difference between binding in CA II and CA IX mimic is in the torsion angle orienting the sulfamate moiety to the A-ring. The nitrogen-sulfur-oxygenC3 torsion angle in the CA II structure is $-157^{\circ}$; whereas in CA IX mimic it is $62^{\circ}$. In the CA II-15 complex the inhibitor orients towards the hydrophobic region of the active site, forming van der Waals contacts with Val 121, Phe 131, Leu 141, Leu 198, Pro 202, and the GOL. His 64 is seen in the dual conformation with the inward coordinating to the GOL. In the CA IX mimic-15 complex, 15 orients towards the hydrophilic side, though the bulk 
of the interactions are hydrophobic, including Asn 62, His 64, His 94, Phe 131, Leu 198, and Thr 200. The orientation switch is most likely caused by a water-mediated hydrogen bond between the carbonyl O17 and Gln 67. In CA II residue 67 is an asparagine, which is too short to coordinate to this O17. This bond is fairly strong in the CA IX mimic with a distance of $2.9 \AA$ to the water and $2.7 \AA$ from the water to the Gln 67.

A second molecule of $\mathbf{1 5}$ is seen sitting on the exterior of the active site in the CA IX mimic-15 complex (Figure 2E and Supplemental Figure 1D). It interacts end on, the D-ring engaged in hydrophobic contacts with the D-ring of the $\mathrm{Zn}^{2+}$-bound 15. The $\mathrm{O} 17$ carbonyl engages in hydrogen bonds of $3.3 \AA$ with the inward conformation of Gln 92 and $3.2 \AA$ with Gln 67. Additionally there is a water-mediated hydrogen bond to Gln 136. The estrone backbone has van der Waals interactions with Pro 202, Ile 91, and Phe 131.

Compound 16 Structural Comparisons. Like 15, 16 has rather distinctive differences between the CA II and CA IX mimic structures (Figure 2B, C, F and Supplemental Figure 1E and F). Once again the orientation of the sulfamate is similar between the two structures, with the $\mathrm{Zn}^{2+}$ coordination, the hydrogen bond with His 96 , the two hydrogen bonds to Thr 199, and the weak interaction with His 94. The difference in sulfamate/A-ring torsion angle resembles $\mathbf{1 5}$ in the rotation. The nitrogen-sulfur-oxygen-C3 torsion angle is $-178^{\circ}$ in CA II and $66^{\circ}$ in CA IX mimic. CA II binds in the hydrophobic region engaged in van der Waals interactions with Val 121, Phe 131, Leu 141, Leu 198, Pro 202 and a GOL. Within the CA IX mimic 16 binds in the hydrophilic site, engaging in hydrophobic contacts with Asn 62, Val 121, Phe 131, Leu 198, and Thr 200. It also contains a water-mediated hydrogen bond between O17 hydroxyl and Gln 67. These hydrogen bond distances are longer than those seen in 15 with an $\mathrm{O} 17$ to water distance of $3.0 \AA$ and a water to Gln 67 distance of $3.3 \AA$.

Binding Energy Comparisons. The crystal structures of the CA-compound complexes were input into the PISA server to assess the binding energy of the molecules (Table 1) [34]. Unsurprisingly 14 showed little difference between the CA II and CA IX mimic structures with values of -4.2 and $-3.2 \mathrm{kcal} / \mathrm{mol}$ respectively. Despite the different orientations of $\mathbf{1 5}$ the $\Delta \mathrm{G}$ was $-2 \mathrm{kcal} / \mathrm{mol}$ for CA II and -2.6 for CA IX mimic, consistent with the similar inhibition constants between the two. Also supporting the inhibition data, $\mathbf{1 6}$ showed a large difference with CA II having a binding energy of $-4 \mathrm{kcal} / \mathrm{mol}$ as compared to the CA IX mimic, which was $-1.2 \mathrm{kcal} / \mathrm{mol}$.

Additionally each of the compound complexes were least squares superposed onto the structure of wt CA IX and the resultant wtCAIX - complex input into the PISA server to identify whether the CA IX mimic data was consistent. Predictably the wt CA IX modeled with $\mathbf{1 4}$ in the CA II and CA IX mimic conformations was nearly 
identical at -3.6 and $-3.7 \mathrm{kcal} / \mathrm{mol}$. Wt CA IX modeled with 15 resulted in a binding energy of $-2.9 \mathrm{kcal} / \mathrm{mol}$ for the CA II orientation and $-2.5 \mathrm{kcal} / \mathrm{mol}$ for the mimic. $\mathbf{1 6}$ in the CA II orientation was calculated to have an energy of $2.8 \mathrm{kcal} / \mathrm{mol}$ while the mimic orientation produced a value of $-1.9 \mathrm{kcal} / \mathrm{mol}$.

\section{Discussion}

When the inhibition data are correlated with the structures a pattern emerges. The identical orientation of $\mathbf{1 4}$ in both the CA II and CA IX mimic probably relates to the free 3-O-sulfamate that extents far outside of the active site into the bulk solvent forming no meaningful interactions. This primary mode of interaction is the coordination of the sulfamate to $\mathrm{Zn}^{2+}$ and between the estrone backbone to the hydrophobic part of the active site (Figure $2 \mathrm{~B} \& \mathrm{C}$ ). The ligand is oriented away from residues 65 and 67 therefore not conferring any significant isozyme specificity. This is reflected by the negligible difference between the $\mathrm{K}_{\mathrm{i}}$ of $\mathbf{1 4}$ in the CA II and in the CA IX mimic as well as the nearly identical binding energies.

The differences seen in the structures of CA II and CA IX mimic complexed with compounds $\mathbf{1 5}$ and $\mathbf{1 6}$ show potential for the design of isozyme specific drugs. The orientations of both compounds seem to relate to a watermediated hydrogen bond between O17 and the Gln 67 in CA IX mimic (Figure 2B and C). Reorienting the compound from the hydrophobic region of the active site into the hydrophilic region reduces the number of contacts along the estrone backbone, and instead makes van der Waals interactions with polar residues. In $\mathbf{1 5}$ the shift seen in CA IX mimic is counterbalanced by an additional hydrophobic contact and the tight water-mediated hydrogen bond. This results in a relatively insignificant affinity preference for CA II over CA IX mimic demonstrated by the small difference in the $\mathrm{K}_{\mathrm{i}}$ as well as the small difference in binding energy. This second $\mathbf{1 5}$ molecule of the 15-CA IX mimic complex shares a direct interaction with Gln 67 that may play a role in the inhibition mechanism, but given its low occupancy any conclusion would be speculation. With compound 16, the hydrophobic to hydrophilic transition in CA IX mimic induces the loss of one van der Waals interaction. Of the five such interactions remaining two are with polar residues (Thr 200 and Asn 62). The longer water-mediated hydrogen bond to Gln 67 fails to compensate for this large shift in environment. These observations therefore present an explaination for the 12-fold reduction in the affinity of compound $\mathbf{1 6}$ for CA IX mimic as compared to CA II and the estimated $2.8 \mathrm{kcal} / \mathrm{mol}$ difference in the binding energy. 
The accuracy of CA IX mimic as a model of wt CA IX is also reinforced by the binding energy calculations of the wt CA IX model with the compounds in their respective CA II and CA IX orientations (Table 1). The values of wt CA IX with the compounds in the CA IX mimic orientations were reasonable consistent with the CA IX mimic values within reasonable error. This indicates that the orientations seen in CA IX mimic are likely applicable to wt CA IX structure.

This discernable difference in affinity reinforces the feasibility of developing an effective and isozyme-specific CA inhibitor, though in this case the specificity is for CA II rather than the anti-cancer target CA IX. That a single water-mediated hydrogen bond can confer a pronounced change in $\mathrm{K}_{\mathrm{i}}$ strengthens the assertion that water should be a consideration in structure-based drug design. Conceivably an inhibitor of similar length with more hydrophilic properties along the backbone could achieve a highly desired, CA IX specific inhibitor that could be used to combat solid tumor growth in numerous cancers.

\begin{abstract}
Abbreviations
The abbreviations used are: CA, carbonic anhydrase; 14, 2-Ethylestradiol-3,17-O,O-bis-sulfamate; 15, 2Ethylestrone-3-O-sulfamate; 16, 2-Ethylestradiol-3- $O$-sulfamate; $\mathrm{GI}_{50}, 50 \%$ growth inhibition concentration; $\mathrm{NCI}$, National Cancer Institute; $\mathrm{K}_{\mathrm{i}}$, inhibition constant; AZM, acetazolamide; GOL, glycerol; wt, wild-type.
\end{abstract}

\title{
Conflict of Interest
}

The authors declare no conflict of interest.

\section{Acknowledgements}

The authors would like to thank Dr. David Silverman for the provision of materials and equipment for the ${ }^{18} \mathrm{O}$ exchange inhibition assay as well as critical manuscript evaluation. This work was supported by NIH Grant GM25154 and by grants from the Medical Research Council of South Africa (AG374, AK076), the Cancer Association of South Africa (AK246), the Struwig-Germeshuysen Cancer Research Trust of South Africa (AJ038) and RESCOM University of Pretoria (A0R984). 


\section{Supportive/Supplementary Material}

Compound synthesis methods, crystallographic statistics, an interaction table and electron density figures can be found in Supplemental Information.

\section{References}

[1] Fotsis, T.; Zhang, Y.; Pepper, M. S.; Adlercreutz, H.; Montesano, R.; Nawroth, P. P.; Schweigerer, L., The endogenous oestrogen metabolite 2-methoxyoestradiol inhibits angiogenesis and suppresses tumour growth. Nature 1994, 368 (6468), 237-9.

[2] Attalla, H.; Makela, T. P.; Adlercreutz, H.; Andersson, L. C., 2-Methoxyestradiol arrests cells in mitosis without depolymerizing tubulin. Biochem Biophys Res Commun 1996, 228 (2), 467-73.

[3] Nakagawa-Yagi, Y.; Ogane, N.; Inoki, Y.; Kitoh, N., The endogenous estrogen metabolite 2-methoxyestradiol induces apoptotic neuronal cell death in vitro. Life Sci 1996, 58 (17), 1461-7.

[4] Mukhopadhyay, T.; Roth, J. A., Induction of apoptosis in human lung cancer cells after wild-type p53 activation by methoxyestradiol. Oncogene 1997, 14 (3), 379-84.

[5] Schumacher, G.; Kataoka, M.; Roth, J. A.; Mukhopadhyay, T., Potent antitumor activity of 2-methoxyestradiol in human pancreatic cancer cell lines. Clin Cancer Res 1999, 5 (3), 493-9.

[6] D'Amato, R. J.; Lin, C. M.; Flynn, E.; Folkman, J.; Hamel, E., 2-Methoxyestradiol, an endogenous mammalian metabolite, inhibits tubulin polymerization by interacting at the colchicine site. Proc Natl Acad Sci US A 1994, 91 (9), 3964-8.

[7] Jordan, M. A.; Wilson, L., Microtubules and actin filaments: dynamic targets for cancer chemotherapy. Curr Opin Cell Biol 1998, 10 (1), 123-30.

[8] Dahut, W. L.; Lakhani, N. J.; Gulley, J. L.; Arlen, P. M.; Kohn, E. C.; Kotz, H.; McNally, D.; Parr, A.; Nguyen, D.; Yang, S. X.; Steinberg, S. M.; Venitz, J.; Sparreboom, A.; Figg, W. D., Phase I clinical trial of oral 2methoxyestradiol, an antiangiogenic and apoptotic agent, in patients with solid tumors. Cancer Biol Ther 2006, 5 (1), 22-7.

[9] Purohit, A.; Hejaz, H. A.; Walden, L.; MacCarthy-Morrogh, L.; Packham, G.; Potter, B. V.; Reed, M. J., The effect of 2-methoxyoestrone-3-O-sulphamate on the growth of breast cancer cells and induced mammary tumours. Int J Cancer 2000, 85 (4), 584-9. 
[10] Purohit, A.; Vernon, K. A.; Hummelinck, A. E.; Woo, L. W.; Hejaz, H. A.; Potter, B. V.; Reed, M. J., The development of A-ring modified analogues of oestrone-3-O-sulphamate as potent steroid sulphatase inhibitors with reduced oestrogenicity. J Steroid Biochem Mol Biol 1998, 64 (5-6), 269-75.

[11] Verma, R. P., An Approach Towards the Quantitative Structure-Activity Relationships for Sulfamate-Based Estrone Sulfatase Inhibitors. Letters in Drug Design \& Discovery 2005, 2 (3), 205-218.

[12] Bubert, C.; Leese, M. P.; Mahon, M. F.; Ferrandis, E.; Regis-Lydi, S.; Kasprzyk, P. G.; Newman, S. P.; Ho, Y. T.; Purohit, A.; Reed, M. J.; Potter, B. V., 3,17-disubstituted 2-alkylestra-1,3,5(10)-trien-3-ol derivatives: synthesis, in vitro and in vivo anticancer activity. $J$ Med Chem 2007, 50 (18), 4431-43.

[13] Leese, M. P.; Hejaz, H. A.; Mahon, M. F.; Newman, S. P.; Purohit, A.; Reed, M. J.; Potter, B. V., A-ringsubstituted estrogen-3-O-sulfamates: potent multitargeted anticancer agents. J Med Chem 2005, 48 (16), 5243-56. [14] Leese, M. P.; Leblond, B.; Smith, A.; Newman, S. P.; Di Fiore, A.; De Simone, G.; Supuran, C. T.; Purohit, A.; Reed, M. J.; Potter, B. V., 2-substituted estradiol bis-sulfamates, multitargeted antitumor agents: synthesis, in vitro SAR, protein crystallography, and in vivo activity. J Med Chem 2006, 49 (26), 7683-96.

[15] Elger, W.; Schwarz, S.; Hedden, A.; Reddersen, G.; Schneider, B., Sulfamates of various estrogens are prodrugs with increased systemic and reduced hepatic estrogenicity at oral application. J Steroid Biochem Mol Biol 1995, 55 (3-4), 395-403.

[16] Abbate, F.; Winum, J. Y.; Potter, B. V.; Casini, A.; Montero, J. L.; Scozzafava, A.; Supuran, C. T., Carbonic anhydrase inhibitors: X-ray crystallographic structure of the adduct of human isozyme II with EMATE, a dual inhibitor of carbonic anhydrases and steroid sulfatase. Bioorg Med Chem Lett 2004, 14 (1), 231-4.

[17] Krishnamurthy, V. M.; Kaufman, G. K.; Urbach, A. R.; Gitlin, I.; Gudiksen, K. L.; Weibel, D. B.; Whitesides, G. M., Carbonic anhydrase as a model for biophysical and physical-organic studies of proteins and protein-ligand binding. Chem Rev 2008, 108 (3), 946-1051.

[18] Supuran, C. T.; Briganti, F.; Tilli, S.; Chegwidden, W. R.; Scozzafava, A., Carbonic anhydrase inhibitors: sulfonamides as antitumor agents? Bioorg Med Chem 2001, 9 (3), 703-14.

[19] Thiry, A.; Dogne, J. M.; Masereel, B.; Supuran, C. T., Targeting tumor-associated carbonic anhydrase IX in cancer therapy. Trends Pharmacol Sci 2006, 27 (11), 566-73.

[20] Guler, O. O.; De Simone, G.; Supuran, C. T., Drug design studies of the novel antitumor targets carbonic anhydrase IX and XII. Curr Med Chem 2010, 17 (15), 1516-26. 
[21] Genis, C.; Sippel, K. H.; Case, N.; Cao, W.; Avvaru, B. S.; Tartaglia, L. J.; Govindasamy, L.; Tu, C.; Agbandje-McKenna, M.; Silverman, D. N.; Rosser, C. J.; McKenna, R., Design of a carbonic anhydrase IX activesite mimic to screen inhibitors for possible anticancer properties. Biochemistry 2009, 48 (6), 1322-31.

[22] Alterio, V.; Hilvo, M.; Di Fiore, A.; Supuran, C. T.; Pan, P.; Parkkila, S.; Scaloni, A.; Pastorek, J.; Pastorekova, S.; Pedone, C.; Scozzafava, A.; Monti, S. M.; De Simone, G., Crystal structure of the catalytic domain of the tumorassociated human carbonic anhydrase IX. Proc Natl Acad Sci U S A 2009, 106 (38), 16233-8.

[23] Cozier, G. E.; Leese, M. P.; Lloyd, M. D.; Baker, M. D.; Thiyagarajan, N.; Acharya, K. R.; Potter, B. V., Structures of human carbonic anhydrase II/inhibitor complexes reveal a second binding site for steroidal and nonsteroidal inhibitors. Biochemistry 2010, 49 (16), 3464-76.

[24] Khalifah, R. G., Histidine-200 alters inhibitor binding in human carbonic anhydrase B. A carbon-13 nuclear magnetic resonance identification. Biochemistry 1977, 16 (10), 2236-40.

[25] Silverman, D. N., Carbonic anhydrase: oxygen-18 exchange catalyzed by an enzyme with rate-contributing proton-transfer steps. Methods Enzymol 1982, 87, 732-52.

[26] Segel, I., Enzyme Kinetics: Behavior and Analysis of Rapid Equilibrium and Steady-State Enzyme Systems. Wiley-Interscience: New York, 1975.

[27] McPherson, A., Preparation and Analysis of Protein Crystals. John Wiley and Sons: New York, 1982.

[28] Otwinowski, Z.; Minor, W., Processing of X-ray Diffraction Data Collected in Oscillation Mode. Yale University: New Haven, CT, USA, 1997; Vol. 276.

[29] Fisher, S. Z.; Maupin, C. M.; Budayova-Spano, M.; Govindasamy, L.; Tu, C.; Agbandje-McKenna, M.; Silverman, D. N.; Voth, G. A.; McKenna, R., Atomic crystal and molecular dynamics simulation structures of human carbonic anhydrase II: insights into the proton transfer mechanism. Biochemistry 2007, 46 (11), 2930-7. [30] Adams, P. D.; Afonine, P. V.; Bunkoczi, G.; Chen, V. B.; Davis, I. W.; Echols, N.; Headd, J. J.; Hung, L. W.; Kapral, G. J.; Grosse-Kunstleve, R. W.; McCoy, A. J.; Moriarty, N. W.; Oeffner, R.; Read, R. J.; Richardson, D. C.; Richardson, J. S.; Terwilliger, T. C.; Zwart, P. H., PHENIX: a comprehensive Python-based system for macromolecular structure solution. Acta Crystallogr D Biol Crystallogr 2010, 66 (Pt 2), 213-21.

[31] Schuttelkopf, A. W.; van Aalten, D. M., PRODRG: a tool for high-throughput crystallography of protein-ligand complexes. Acta Crystallogr D Biol Crystallogr 2004, 60 (Pt 8), 1355-63. 
[32] Emsley, P.; Cowtan, K., Coot: model-building tools for molecular graphics. Acta Crystallogr D Biol Crystallogr 2004, 60 (Pt 12 Pt 1), 2126-32.

[33] Wallace, A. C.; Laskowski, R. A.; Thornton, J. M., LIGPLOT: a program to generate schematic diagrams of protein-ligand interactions. Protein Eng 1995, 8 (2), 127-34.

[34] Krissinel, E.; Henrick, K., Inference of macromolecular assemblies from crystalline state. J Mol Biol 2007, 372 (3), 774-97.

[35] Praaenikar, J.; Afonine, P. V.; Guncar, G.; Adams, P. D.; Turk, D., Averaged kick maps: less noise, more signal... and probably less bias. Acta Crystallogr D Biol Crystallogr 2009, 65 (Pt 9), 921-31.

[36] DeLano, W. L. The Pymol Molecular Graphics System, Delano Scientific: Palo Alto, CA, USA, 2002.

\section{Figure Legend}

Figure 12 -ethylestra compound formulas and names. Letters indicate ring designations.

Figure 2 Structural comparisons between wt CA IX, CA IX mimic and CA II. (A) Superposition of wt CA IX (PDB ID 3iai) and CA IX mimic (PDB ID 3dc3) in complex with AZM. AZM is represented by lines; side chains by sticks. Coloring scheme is as follows: wt CA IX carbons, light blue; CA IX mimic carbons, yellow; oxygen, red; nitrogen, blue; and sulfur, gold. The large gray spheres represent $\mathrm{Zn}^{2+}$. Waters are small spheres colored the same as their respective carbons. The orientation of compounds 14, 15, and 16 in a surface rendering of the CA II (B) and the CA IX mimic (C) active sites. Hydrophobic regions are colored purple, hydrophilic regions are blue. Stick coloring is as follows: CA-14 complex carbons are colored magenta; CA-15 complex carbons, yellow; CA-16 complex carbons are teal. Oxygen, nitrogen, sulfur, water, and zinc are colored as described in (A). Stereo image of (D) 14, (E) 15, and (F) 16 active site superpositions with interacting residues shown as sticks. Residues are colored as follows: carbons from the CA II complex, light blue; carbons from the CA IX mimic complex, orange; oxygens, red; nitrogens, dark blue; sulfur, gold. $\mathrm{Zn}^{2+}$ is represented by a large gray sphere. Small spheres colored the same as their respective carbons represent waters. Figure generated in Pymol [36]. 
Table 1 Experimental inhibition constants and theoretical energy calculations of CA-compound complexes.

\begin{tabular}{|l|c|c|}
\hline \multicolumn{1}{|c|}{ Complex } & $\mathbf{K}_{\mathbf{i}}(\mathbf{n M})$ & $\Delta \mathbf{G} \mathbf{~ ( k c a l / m o l )}$ \\
\hline CA II - 14 & $880 \pm 70$ & -4.2 \\
\hline CA IX mimic - 14 & $680 \pm 40$ & -3.2 \\
\hline CA IX: ${ }^{\mathrm{a}}$ CA II-14 & $\mathrm{n} / \mathrm{a}^{\mathrm{b}}$ & -3.6 \\
\hline CA IX: CA IX mimic-14 & $\mathrm{n} / \mathrm{a}$ & -3.7 \\
\hline CA II - 15 & $440 \pm 50$ & -2 \\
\hline CA IX mimic - 15 & $590 \pm 30$ & -2.6 \\
\hline CA IX: CA II-15 & $\mathrm{n} / \mathrm{a}$ & -2.9 \\
\hline CA IX: CA IX mimic-15 & $\mathrm{n} / \mathrm{a}$ & -2.5 \\
\hline CA II - 16 & $180 \pm 10$ & -4 \\
\hline CA IX mimic - 16 & $2100 \pm 220$ & -1.2 \\
\hline CA IX: CA II-16 & $\mathrm{n} / \mathrm{a}$ & -2.8 \\
\hline CA IX: CA IX mimic-16 & $\mathrm{n} / \mathrm{a}$ & -1.9 \\
\hline
\end{tabular}

${ }^{\mathrm{a}} \mathrm{CA}$ IX values are obtained the insertion of compound coordinates from the least-squares superposition of wt-CA IX (PDB ID 3iai chain A) onto the coordinates of the respective complex.

${ }^{b}$ Experimental inhibition constants are not available 
14: 2-Ethylestradiol-3,17-O,O-bis-sulfamate

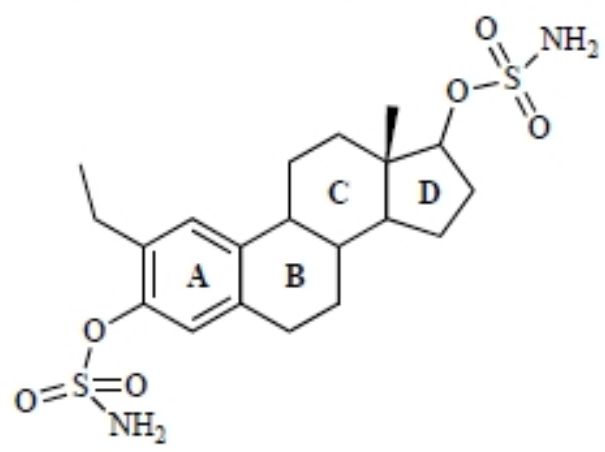

15: 2-Ethylestrone-3-O-sulfamate

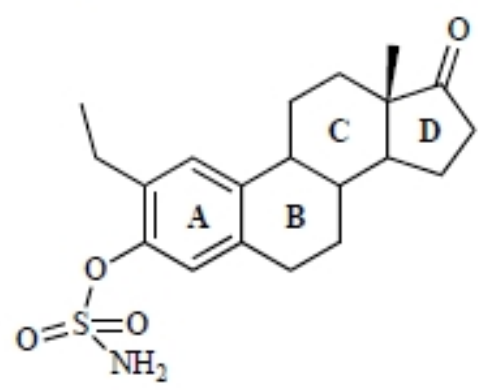

16: 2-Ethylestradiol-3-O-sulfamate

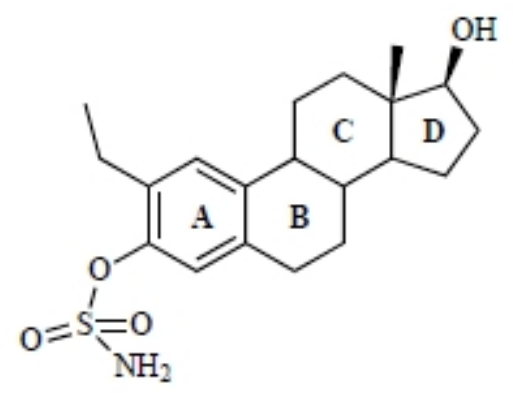

Fig. (1). 2-ethylestra compound formulas and names. Letters indicate ring designations. 

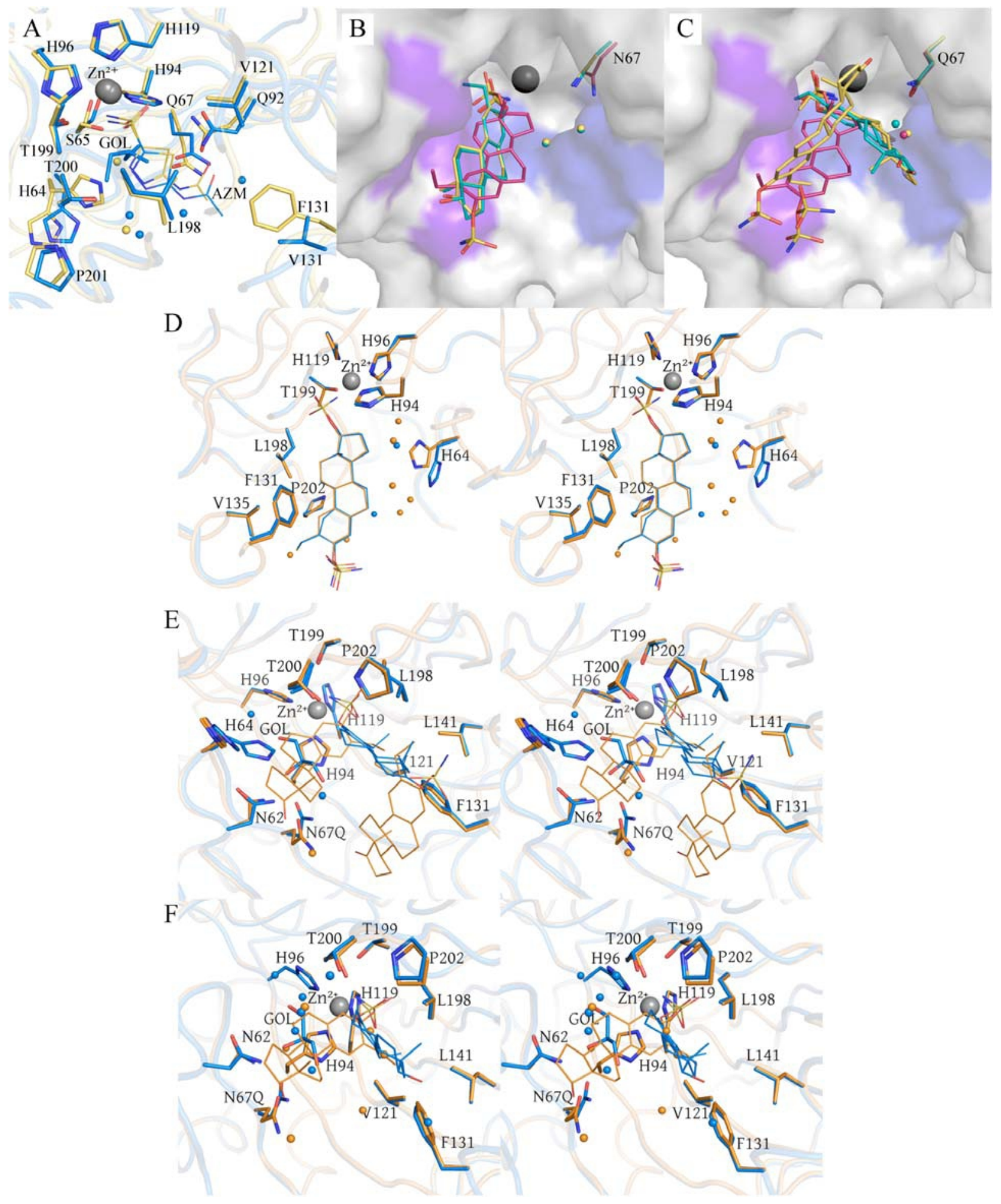

Fig. (2). Structural comparisons between wt CA IX, CA IX mimic and CA II. (A) Superposition of wt CA IX (PDB ID 3iai) and CA IX mimic (PDB ID 3dc3) in complex with AZM. AZM is represented by lines; side chains by sticks. Coloring scheme is as follows: wt CA IX carbons, light blue; CA IX mimic carbons, yellow; oxygen, red; nitrogen, blue; and sulfur, gold. The large gray spheres represent $\mathrm{Zn}_{2}+$. Waters are small spheres colored the same as their respective carbons. The orientation of compounds 
14, 15, and $\mathbf{1 6}$ in a surface rendering of the CA II (B) and the CA IX mimic (C) active sites. Hydrophobic regions are colored purple, hydrophilic regions are blue. Stick coloring is as follows: CA-14 complex carbons are colored magenta; CA-15 complex carbons, yellow; CA-16 complex carbons are teal. Oxygen, nitrogen, sulfur, water, and zinc are colored as described in (A). Stereo image of (D) 14, (E) 15, and (F) 16 active site superpositions with interacting residues shown as sticks. Residues are colored as follows: carbons from the CA II complex, light blue; carbons from the CA IX mimic complex, orange; oxygens, red; nitrogens, dark blue; sulfur, gold. $\mathrm{Zn}_{2}+$ is represented by a large gray sphere. Small spheres colored the same as their respective carbons represent waters. Figure generated in Pymol [36]. 


\section{Supplemental Information}

\section{Chemical Synthesis}

All chemicals were purchased from Aldrich Chemical Co. Organic solvents of A.R. grade were used as supplied. Anhydrous $N, N$-dimethylformamide and $N, N$-dimethylacetamide were purchased from Aldrich and stored under a positive pressure of $\mathrm{N}_{2}$ after use. Tetrahydrofuran was distilled from sodium. Sulfamoyl chloride was prepared by an adaptation of the method of Appel and Berger and stored in a tightly sealed container in the fridge (1). Chromatography was performed on silica gel (70-230 mesh, Macherey Nagel). Thin layer chromatography was performed on Alugram ${ }^{\circledR}$ SIL G/UV ${ }_{254}$ aluminium backed plates (Macherey Nagel). Products were visualized with basic potassium permanganate solution. ${ }^{1} \mathrm{H}$ NMR spectra were recorded in deuterated chloroform solution (unless otherwise indicated) with a Varian $400 \mathrm{NMR}$ spectrometer at $400 \mathrm{MHz}$. Chemical shifts are reported in parts per million (ppm, d) relative to tetramethylsilane (TMS) as an internal standard. The chemical formula for intermediate compounds 1, 2, 3, 4, 5, and 13 are described in Supplemental Fig. 2 and for compounds 14, 15, and 16 are in Fig. 1.

17,17-Ethylenedioxy Estrone. 17,17-Ethylenedioxy estrone was synthesized according to a literature procedure (2). A suspension of estrone $(27.24 \mathrm{~g}, 101 \mathrm{mmol})$, toluene $\left(300 \mathrm{~cm}^{3}\right)$, ethylene glycol $\left(30.00 \mathrm{~cm}^{3}, 592 \mathrm{mmol}\right)$ and $p$-toluenesulfonic acid $(0.250 \mathrm{~g}, 1.45 \mathrm{mmol})$ was refluxed for 16 hours under Dean-Stark conditions. About $2.20 \mathrm{ml}$ of water was collected. The purple reaction mixture was cooled to ambient temperature and poured onto a saturated solution of sodium hydrogen carbonate $\left(300 \mathrm{~cm}^{3}\right)$ and diluted with ethyl acetate $\left(500 \mathrm{~cm}^{3}\right)$. The organic layer was separated and the aqueous layer was extracted with additional ethyl acetate $\left(200 \mathrm{~cm}^{3}\right)$. The combined organic extract was washed with water $\left(400 \mathrm{~cm}^{3}\right)$ and brine $\left(400 \mathrm{~cm}^{3}\right)$. The yellow organic extract was dried over sodium sulfate, filtered and evaporated to give crude compound 2 (31.5 g, $100 \mathrm{mmol}, 99 \%$ yield) as an off-white solid which was used without further purification. An analytical sample was prepared by recrystallization from methanol: ${ }^{1} \mathrm{H}$ NMR (400 $\left.\mathrm{MHz}, C \mathrm{Cl}_{3}\right) \mathrm{d} 7.14(\mathrm{~d}, J=8.4 \mathrm{~Hz}, 1 \mathrm{H}), 6.61(\mathrm{dd}, J=2.7,8.4 \mathrm{~Hz}, 1 \mathrm{H}), 6.55(\mathrm{~d}, J=2.7 \mathrm{~Hz}, 1 \mathrm{H}), 5.10(\mathrm{~s}$, $1 \mathrm{H}), 4.00-3.84(\mathrm{~m}, 4 \mathrm{H}), 2.91-2.70(\mathrm{~m}, 2 \mathrm{H}), 2.40-1.20(\mathrm{~m}, 13 \mathrm{H}), 0.88(\mathrm{~s}, 1 \mathrm{H})$. The NMR data matched those in the literature (2).

Compound 3. Compound 3 was synthesized according to a literature procedure (2). Sodium hydride $(60 \%$ dispersion in oil, $5.72 \mathrm{~g}, 143 \mathrm{mmol})$ was added in a portionwise manner to a stirred $0^{\circ} \mathrm{C}$ solution of compound $2(30.0 \mathrm{~g}, 95 \mathrm{mmol})$ in anhydrous $N, N$-dimethylformamide $\left(420 \mathrm{~cm}^{3}\right)$. The cooling bath was removed and stirring was continued at ambient temperature until the evolution of hydrogen had ceased. This took about 4 hours. The orange reaction mixture was recooled to $0^{\circ} \mathrm{C}$ and methyl chloromethyl ether $\left(14.50 \mathrm{~cm}^{3}, 191 \mathrm{mmol}\right)$ was cautiously added dropwise. Upon complete addition, the cooling bath was removed and the milky reaction mixture was allowed to stir at ambient temperature for 16 hours. Ammonia $\left(2 \mathrm{M}, 180 \mathrm{~cm}^{3}\right)$ was cautiously added to destroy excess methyl chloromethyl ether and sodium hydride. The aqueous reaction mixture was extracted once with ethyl acetate $\left(850 \mathrm{~cm}^{3}\right)$ and the organic extract was washed with brine $\left(5 \times 300 \mathrm{~cm}^{3}\right)$. The organic extract was dried over sodium sulfate, filtered and evaporated to give an oil. Column chromatography ( $10 \%$ ethyl acetate/hexane) afforded compound $\mathbf{3}$ ( $28.12 \mathrm{~g}, 78 \mathrm{mmol}, 82 \%$ yield) as a viscous colourless oil that solidified on standing: $R_{f} 0.54$ (9:1 hexane/ethyl acetate). ${ }^{1} \mathrm{H}$ NMR $\left(400 \mathrm{MHz}, C D C l_{3}\right) \mathrm{d} 7.20(\mathrm{~d}, J=8.5 \mathrm{~Hz}, 1 \mathrm{H}), 6.82$ $(\mathrm{dd}, J=2.7,8.5 \mathrm{~Hz}, 1 \mathrm{H}), 6.76(\mathrm{~d}, J=2.7 \mathrm{~Hz}, 1 \mathrm{H}), 5.13(\mathrm{~s}, 1 \mathrm{H}), 4.02-3.84(\mathrm{~m}, 4 \mathrm{H}), 3.47(\mathrm{~s}, 3 \mathrm{H}), 2.90-$ $2.77(\mathrm{~m}, 2 \mathrm{H}), 2.40-2.17(\mathrm{~m}, 2 \mathrm{H}), 2.10-1.20(\mathrm{~m}, 11 \mathrm{H}), 0.88(\mathrm{~s}, 3 \mathrm{H})$. The NMR data matched those in the literature (2).

Compound 4. Compound 4 was synthesized according to a modified literature procedure (2). A well-stirred solution of tetramethylethylenediamine $\left(20.00 \mathrm{~cm}^{3}, 133 \mathrm{mmol}\right)$ in dry tetrahydrofuran $(210$ $\mathrm{cm}^{3}$ ) was cooled to $-78^{\circ} \mathrm{C}$ and then treated with $n$-butyllithium $\left(1.6 \mathrm{M}, 80.00 \mathrm{~cm}^{3}, 128 \mathrm{mmol}\right)$ over 10 minutes. The reaction mixture was stirred at that temperature for an additional 15 minutes. Compound $\mathbf{3}$ $(15.01 \mathrm{~g}, 41.9 \mathrm{mmol})$ in dry tetrahydrofuran $\left(210 \mathrm{~cm}^{3}\right)$ was added by way of canula over 10 minutes. The reaction mixture was allowed to gradually warm to $0^{\circ} \mathrm{C}$. This took about 6 hours. The reaction mixture 
was maintained at this temperature for an additional 30 minutes and then allowed to stir at ambient temperature for 15 minutes. The reaction mixture was re-cooled to $-78^{\circ} \mathrm{C}$ and iodoethane $\left(10 \mathrm{~cm}^{3}, 124\right.$ $\mathrm{mmol}$ ) was added over 5 minutes. The reaction mixture was allowed to warm to ambient temperature over 2 hours and then carefully quenched with a saturated solution of aqueous ammonium chloride $\left(50 \mathrm{~cm}^{3}\right)$. The aqueous reaction mixture was diluted with ethyl acetate $\left(1000 \mathrm{~cm}^{3}\right)$ and water $\left(50 \mathrm{~cm}^{3}\right)$ and the organic phase was separated. The organic extract was washed with an aqueous solution of sodium thiosulphite $\left(10 \% \mathrm{~m} / \mathrm{v}, 200 \mathrm{~cm}^{3}\right)$, more water $\left(2 \times 100 \mathrm{~cm}^{3}\right)$ and finally with brine $\left(100 \mathrm{~cm}^{3}\right)$. The organic extract was dried over sodium sulfate, filtered and evaporated to give a pale yellow oil (17.02 g). Two column chromatographic (2.5\% ethyl acetate/hexane) purifications afforded compound 4 (7.00 g, 18.1 mmol, $43 \%$ yield) as a viscous colourless oil. An analytical sample was recrystallized from methanol: $R_{f}$ $0.10\left(97.5: 2.5\right.$ hexane/ethyl acetate). ${ }^{1} \mathrm{H}$ NMR $\left(400 \mathrm{MHz}, C D C l_{3}\right) \mathrm{d} 7.08(\mathrm{~s}, 1 \mathrm{H}), 6.78(\mathrm{~s}, 1 \mathrm{H}), 5.16(\mathrm{~s}$, $2 \mathrm{H}), 4.02-3.82(\mathrm{~m}, 4 \mathrm{H}), 3.48(\mathrm{~s}, 3 \mathrm{H}), 2.92-2.73(\mathrm{~m}, 2 \mathrm{H}), 2.62$ (q, $J=7.4 \mathrm{~Hz}, 2 \mathrm{H}), 2.41-2.16(\mathrm{~m}, 2 \mathrm{H})$, 2.10-1.95 (m, 1H), 1.94-1.70 (m, 4H), 1.70-1.28 (m, 6H), $1.19(\mathrm{t}, J=7.5 \mathrm{~Hz}, 3 \mathrm{H}), 0.88(\mathrm{~s}, 3 \mathrm{H})$. The NMR data matched those in the literature (2). Further elution of the column afforded starting material (8.00 g, $22.3 \mathrm{mmol}, 53 \%$ recovery).

Compound 5. Compound 5 was synthesized according to a literature procedure (2). Methanol (68 $\left.\mathrm{cm}^{3}\right)$ was cooled to $0^{\circ} \mathrm{C}$ and cautiously treated with acetyl chloride $\left(24 \mathrm{~cm}^{3}\right)$ and stirred for 10 minutes under nitrogen. The methanolic $\mathrm{HCl}$ solution was then added to a slurry of compound $4(5.000 \mathrm{~g}, 12.94$ mmol) in methanol $\left(32 \mathrm{~cm}^{3}\right)$ and stirred for 1 hour until all the solids had dissolved. Water $\left(100 \mathrm{~cm}^{3}\right)$ was added slowly, and the reaction mixture was cooled in an ice-bath causing precipitation of the product as a white powder which was collected by filtration and washed with water $\left(2 \times 50 \mathrm{~cm}^{3}\right)$. The solid was airdried under suction for 2 hours before being further dried under high-vacuum for 1 hour to afford compound 5 (3.750 g, $12.57 \mathrm{mmol}, 97 \%$ yield) as a fluffy white solid. An analytical sample was recrystallized from methanol: $R_{f} 0.55$ (1:2 hexane/ethyl acetate). ${ }^{1} \mathrm{H}$ NMR $\left(400 \mathrm{MHz}, C D C l_{3}\right) \mathrm{d} 7.05$ (s, $1 \mathrm{H}), 6.52(\mathrm{~s}, 1 \mathrm{H}), 4.63(\mathrm{~s}, 1 \mathrm{H}), 2.88-2.79(\mathrm{~m}, 2 \mathrm{H}), 2.60(\mathrm{q}, J=7.6 \mathrm{~Hz}, 2 \mathrm{H}), 2.56-2.37(\mathrm{~m}, 2 \mathrm{H}), 2.29-1.91$ $(\mathrm{m}, 5 \mathrm{H}), 1.72-1.34(\mathrm{~m}, 6 \mathrm{H}), 1.22(\mathrm{t}, J=7.6 \mathrm{~Hz}, 3 \mathrm{H}), 0.91(\mathrm{~s}, 3 \mathrm{H})$. The NMR data matched those in the literature (2).

Compound 13. Compound $5(0.300 \mathrm{~g}, 1.00 \mathrm{mmol})$ was added to a solution of water/ tetrahydrofuran/ ethanol $\left(1: 1: 1,30 \mathrm{~cm}^{3}\right)$ and stirred at $0^{\circ} \mathrm{C}$. Sodium borohydride $(0.076 \mathrm{~g}, 2.01 \mathrm{mmol})$ was added in one portion. Stirring was continued for 16 hours. Excess sodium borohydride was decomposed with acetic acid $\left(1.00 \mathrm{~cm}^{3}\right)$, the solvent evaporated, and the residue extracted with ethyl acetate $\left(10 \mathrm{~cm}^{3}\right)$. The organic extract was washed with water $\left(5 \mathrm{~cm}^{3}\right)$ and brine $\left(5 \mathrm{~cm}^{3}\right)$. The organic extract was dried over sodium sulfate and evaporated to give a white powder. The powder was recrystallized from diethyl ether/hexane to give compound $13(0.280 \mathrm{~g}, 0.93 \mathrm{mmol}, 93 \%$ yield $)$ as a fluffy white powder: ${ }^{1} \mathrm{H}$ NMR $\left(400 \mathrm{MHz}, C D C l_{3)}\right)$ d $7.05(\mathrm{~s}, 1 \mathrm{H}), 6.49(\mathrm{~s}, 1 \mathrm{H}), 4.59(\mathrm{~s}, 1 \mathrm{H}), 3.73(\mathrm{t}, J=8.5 \mathrm{~Hz}, 1 \mathrm{H}), 2.87-2.70(\mathrm{~m}, 2 \mathrm{H})$, $2.59(\mathrm{q}, J=7.5 \mathrm{~Hz}, 2 \mathrm{H}), 2.40-2.28(\mathrm{~m}, 1 \mathrm{H}), 2.24-2.05(\mathrm{~m}, 2 \mathrm{H}), 1.99-1.92(\mathrm{~m}, 1 \mathrm{H}), 1.91-1.81(\mathrm{~m}, 1 \mathrm{H})$, 1.76-1.62 (m, 1H), 1.56-1.19 (m, $11 \mathrm{H}$, containing t, $J=7.5 \mathrm{~Hz}, 3 \mathrm{H}), 0.78(\mathrm{~s}, 3 \mathrm{H})$.

Compound 14. Sulfamoyl chloride $(0.231 \mathrm{~g}, 2.00 \mathrm{mmol})$ was added to an ice-cold solution of compound $13(0.100 \mathrm{~g}, 0.33 \mathrm{mmol})$ in $N, N$-dimethylacetamide $\left(5.00 \mathrm{~cm}^{3}\right)$. The reaction was allowed to warm to ambient temperature overnight. Cold brine $\left(5 \mathrm{~cm}^{3}\right)$ was added and the aqueous reaction mixture was extracted with ethyl acetate $\left(3 \times 20 \mathrm{~cm}^{3}\right)$. The organic layer was dried over sodium sulfate, filtered and evaporated to to give a yellow solid. Column chromatography ( $10 \%$ acetone/chloroform) followed by trituration with chloroform/hexane mixtures afforded compound 14 (0.065 g, $0.14 \mathrm{mmol}, 43 \%$ yield) as an off-white solid. The solid was stored in the freezer when not in use: $R_{f} 0.10$ (1:9 acetone/chloroform). ${ }^{1} \mathrm{H}$ NMR $\left(400 \mathrm{MHz}, d_{6}-D M S O\right)$ d 7.71 (br s, 2H), 7.17 (br s, 2H), $7.16(\mathrm{~s}, 1 \mathrm{H}), 7.06(\mathrm{~s}, 1 \mathrm{H}), 4.39$ (dd, $J=$ 7.0, $9.0 \mathrm{~Hz}, 1 \mathrm{H}), 2.86-2.77$ (m, 2H), 2.67 (q, $J=7.5 \mathrm{~Hz}, 2 \mathrm{H}), 2.44-2.14(\mathrm{~m}, 3 \mathrm{H}), 2.07-1.98(\mathrm{~m}, 1 \mathrm{H}), 1.94$ $1.85(\mathrm{~m}, 1 \mathrm{H}), 1.82-1.71(\mathrm{~m}, 2 \mathrm{H}), 1.51-1.13(\mathrm{~m}, 9 \mathrm{H}$, containing t, $J=7.5 \mathrm{~Hz}, 3 \mathrm{H}), 0.82(\mathrm{~s}, 3 \mathrm{H})$.

Compound 15. Synthesized according to a literature procedure (2). Sulfamoyl chloride $(0.347 \mathrm{~g}$, $3.00 \mathrm{mmol})$ was added to an ice-cold solution of compound $5(0.300 \mathrm{~g}, 1.00 \mathrm{mmol})$ in $\mathrm{N}, \mathrm{N}$ dimethylacetamide $\left(1.50 \mathrm{~cm}^{3}\right)$. The reaction was allowed to warm to ambient temperature overnight. Ethyl acetate $\left(25 \mathrm{~cm}^{3}\right)$ and water $\left(25 \mathrm{~cm}^{3}\right)$ were added, and the organic layer was separated and washed 
with additional water $\left(4 \times 25 \mathrm{~cm}^{3}\right)$ and brine $\left(25 \mathrm{~cm}^{3}\right)$. The organic extract was dried over sodium sulfate, filtered and evaporated to give a yellow oil. Column chromatography (10\% acetone/chloroform) afforded compound $15(0.300 \mathrm{~g}, 0.80 \mathrm{mmol}, 79 \%$ yield $)$ as a white powder. The solid was stored in the freezer when not in use: $R_{f} 0.4$ (1:9 acetone/chloroform). ${ }^{1} \mathrm{H}$ NMR $\left(400 \mathrm{MHz}, C D C l_{3}\right) \mathrm{d} 7.20(\mathrm{~s}, 1 \mathrm{H}), 7.11(\mathrm{~s}$, $1 \mathrm{H}), 4.93$ (s, 2H), 2.95-2.85 (m, 2H), 2.70 (q, $J=7.6 \mathrm{~Hz}, 2 \mathrm{H}), 2.56-2.38(\mathrm{~m}, 2 \mathrm{H}), 2.34-2.22(\mathrm{~m}, 1 \mathrm{H})$, 2.22-1.91 (m, 4H), 1.70-1.37 (m, 6H), $1.22(\mathrm{t}, J=7.6 \mathrm{~Hz}, 3 \mathrm{H}), 0.91(\mathrm{~s}, 3 \mathrm{H})$. The NMR data matched those in the literature (2).

Compound 16. Synthesized according to a literature procedure (2). To a solution of compound 15 $(0.150 \mathrm{~g}, 0.40 \mathrm{mmol})$ in tetrahydrofuran $\left(2.5 \mathrm{~cm}^{3}\right)$ and 2-propanol $\left(10 \mathrm{~cm}^{3}\right)$ was added sodium borohydride $(0.030 \mathrm{~g}, 0.79 \mathrm{mmol})$ in a portionwise manner. The reaction was stirred at ambient temperature for 2 hours. A saturated solution of ammonium chloride $\left(1.50 \mathrm{~cm}^{3}\right)$ was carefully added to the reaction mixture and the aqueous reaction mixture was left to stand overnight. Water $\left(30 \mathrm{~cm}^{3}\right)$ was added and the aqueous reaction mixture was extracted with ethyl acetate $\left(2 \times 50 \mathrm{~cm}^{3}\right)$. The organic extract was washed with water $\left(20 \mathrm{~cm}^{3}\right)$ and brine $\left(20 \mathrm{~cm}^{3}\right)$. The organic extract was dried over sodium sulfate, filtered and evaporated to give a yellow solid. Column chromatography ( $20 \%$ ethyl acetate/hexane) afforded compound $16(0.137 \mathrm{~g}, 0.36 \mathrm{mmol}, 91 \%$ yield $)$ as a white solid. The solid was stored in the freezer when not in use: $R_{f} 0.40$ (3:2 hexane/ethyl acetate). ${ }^{1} \mathrm{H}$ NMR (400 MHz, $C D C l_{3}+2$ drops $d_{6^{-}}$ DMSO) d $7.18(\mathrm{~s}, 1 \mathrm{H}), 7.10(\mathrm{~s}, 1 \mathrm{H}), 6.63(\mathrm{br} \mathrm{s}, 2 \mathrm{H}), 3.83-3.62(\mathrm{~m}, 1 \mathrm{H}), 2.83(\mathrm{dd}, J=4.1,8.8 \mathrm{~Hz}, 2 \mathrm{H})$, $2.71(\mathrm{q}, J=7.5 \mathrm{~Hz}, 2 \mathrm{H}), 2.53(\mathrm{~d}, J=5.60 \mathrm{~Hz}, 1 \mathrm{H}), 2.38-2.29(\mathrm{~m}, 1 \mathrm{H}), 2.25-2.04(\mathrm{~m}, 2 \mathrm{H}), 1.98(\mathrm{td}, J=$ $3.3,12.6 \mathrm{~Hz}, 1 \mathrm{H}), 1.93-1.84(\mathrm{~m}, 1 \mathrm{H}), 1.75-1.63(\mathrm{~m}, 1 \mathrm{H}), 1.56-1.16(\mathrm{~m}, 11 \mathrm{H}$ containing $\mathrm{t}, J=7.5 \mathrm{~Hz}, 3 \mathrm{H})$, $0.77(\mathrm{~s}, 3 \mathrm{H})$. The NMR data matched those in the literature (2). 
Supplemental Table 1. Data and refinement statistics.

\begin{tabular}{|c|c|c|c|c|c|}
\hline Data Statistics & 14 - CA IX mimic & 15 - CA II & 15 - CA IX mimic & 16 - CA II & 16 - CA IX mimic \\
\hline Space Group & $\mathrm{P} 2_{1}$ & $\mathrm{P} 2_{1}$ & $\mathrm{P} 2_{1}$ & $\mathrm{P} 2_{1}$ & $\mathrm{P} 2_{1}$ \\
\hline \multirow{4}{*}{ Unit-cell parameters $(\AA, \circ)$} & $a=42.2$ & $a=42.2$ & $a=42.3$ & $a=42.2$ & $a=42.1$ \\
\hline & $b=41.3$ & $b=41.2$ & $b=41.3$ & $b=41.2$ & $b=41.3$ \\
\hline & $c=72.2$ & $c=71.5$ & $c=72.4$ & $c=71.3$ & $c=71.6$ \\
\hline & $\beta=104.3$ & $\beta=104.1$ & $\beta=104.3$ & $\beta=104.0$ & $\beta=104.1$ \\
\hline Resolution $(\AA)$ & $25.3-1.5(1.55-1.5)^{\mathrm{a}}$ & $23.1-1.45(1.5-1.45)$ & $28.7-1.45(1.5-1.45)$ & $23.8-1.45(1.5-1.45)$ & $23.1-1.5(1.55-1.50)$ \\
\hline $\mathrm{R}_{\mathrm{sym}}^{\mathrm{b}}$ & $0.057(0.39)$ & $0.055(0.21)$ & $0.051(0.181)$ & $0.048(0.25)$ & $0.025(0.090)$ \\
\hline $\mathrm{I} / \sigma \mathrm{I}$ & $25.9(4.0)$ & $28.4(6.0)$ & $28.5(8.0)$ & $29.8(4.5)$ & $48.3(14.7)$ \\
\hline Number of Unique Reflections & 35886 & 40524 & 40167 & 39564 & 36899 \\
\hline Redundancy & $5.1(4.8)$ & $4.7(3.5)$ & $5.8(4.5)$ & $4.4(3.5)$ & $3.6(3.4)$ \\
\hline Completeness (\%) & $93.5(89.3)$ & $95.3(80.3)$ & $94.0(76.9)$ & $94.1(77.9)$ & $95.9(91.1)$ \\
\hline \multicolumn{6}{|l|}{ Refinement Statistics } \\
\hline $\mathrm{R}_{\text {cryst }}{ }^{\mathrm{c}} / \mathrm{R}_{\text {free }}{ }^{\mathrm{d}}(\%)$ & $12.9 / 16.3$ & $14.2 / 15.9$ & $13.2 / 14.7$ & $13.4 / 17.0$ & $13.7 / 17.4$ \\
\hline \multicolumn{6}{|l|}{ Non-H atoms } \\
\hline Protein & 2256 & 2245 & 2293 & 2246 & 2235 \\
\hline Solvent / Other & $374 / 42$ & $359 / 37$ & $389 / 57$ & $336 / 37$ & $388 / 27$ \\
\hline \multicolumn{6}{|l|}{ Root mean square deviation } \\
\hline Bond lengths ( $\AA)$ & 0.012 & 0.009 & 0.009 & 0.013 & 0.012 \\
\hline $\operatorname{Angles}\left({ }^{\circ}\right)$ & 1.56 & 1.40 & 1.38 & 1.67 & 1.50 \\
\hline \multicolumn{6}{|l|}{ Average $B$ factors $\left(\AA^{2}\right)$} \\
\hline Main chain /side chain & $12.5 / 16.7$ & $15.6 / 19.8$ & $12.7 / 16.7$ & $17.2 / 20.4$ & $14.4 / 18.6$ \\
\hline Solvent / inhibitor & $15.8 / 31.3$ & $29.8 / 25.4$ & $27.9 / 21.8$ & $31.0 / 17.1$ & $29.2 / 18.4$ \\
\hline \multicolumn{6}{|l|}{ Ramachandran statistics (\%) } \\
\hline Most favored & 96.9 & 97.2 & 96.3 & 96.3 & 96.9 \\
\hline Allowed & 3.1 & 2.8 & 3.7 & 3.7 & 3.1 \\
\hline Outliers & 0 & 0 & 0 & 0 & 0 \\
\hline PDB-ID & 3oik & 3oku & 3okv & 3oim & 3oil \\
\hline
\end{tabular}

${ }^{a}$ Values in parenthesis are for highest resolution shell.

${ }^{\mathrm{b}} \mathrm{R}_{\text {sym }}=(\Sigma|\mathrm{I}-<\mathrm{I}>| / \Sigma<\mathrm{I}>) \times 100$.

${ }^{c} \mathrm{R}_{\text {cryst }}=\left(\Sigma\left|\mathrm{F}_{\text {obs }}\right|-\left|\mathrm{F}_{\mathrm{c}}\right| / \Sigma\left|\mathrm{F}_{\text {obs }}\right|\right) \times 100$.

${ }^{d} R_{\text {free }}$ is calculated the same as $R_{\text {cryst }}$, except it uses $5 \%$ of reflection data omitted from refinement. 
Supplemental Table 2. Interaction Table. Distances in $\AA$ listed in parenthesis.

\begin{tabular}{|c|c|c|}
\hline $\begin{array}{l}\text { Compound } \\
\text { (PDB ligand } \\
\text { code) }\end{array}$ & CA II & CA IX mimic \\
\hline $14(\mathrm{WZB})$ & $\begin{array}{l}\text { a,b HB: T199 }(2.6+3.0), \text { H94 (3.3) } \\
\text { Zn }^{2+}(2.1) \\
{ }^{\mathbf{c}} \mathbf{H C}: \text { P202, L198, V135, F131 } \\
{ }^{\mathbf{d}} \mathbf{T C A :} 3330 \AA^{2}\end{array}$ & $\begin{array}{l}\text { HB: } \mathrm{T} 199(3.0+2.8), \mathrm{Zn}^{2+}(1.9) \\
\text { HC: } \mathrm{H} 94, \mathrm{P} 202, \mathrm{~L} 198, \mathrm{~V} 135, \mathrm{~F} 131 \text {, } \\
\quad \text { H64 } \\
\text { TCA: } 3456 \AA^{2}\end{array}$ \\
\hline 15 (VZ4) & $\begin{array}{l}\text { HB: } \mathrm{T} 199(2.9), \mathrm{H} 96(3.3), \mathrm{H} 119 \\
\quad(3.3), \mathrm{Zn}^{2+}(2.0) \\
\text { HC: P202, L198, F131, L141, V121, } \\
\quad{ }^{\text {GOL }} \\
\text { TCA: } 3423 \AA^{2}\end{array}$ & $\begin{array}{l}\text { Molecule } 1 \text { - } \\
\text { HB: T199 (2.74), H96 (3.3), H119 } \\
\quad(3.3),(\mathrm{wm}), \mathrm{Zn}^{2+}(2.0) \\
\text { HC: T200, L198, H64, N62, F131, } \\
\text { H94, VZ4 molecule } 2 \\
\text { TCA: } 3364 \AA^{2} \\
\text { Molecule 2- } \\
\text { HB: Q92 (3.3), G132 (wm), Q136 } \\
\text { (wm), Q67 (3.2) } \\
\text { HC: P202, L204, I91, F131, VZ4 } \\
\text { molecule } 1 \\
\text { TCA: } 3393 \AA^{2}\end{array}$ \\
\hline 16 (VZ5) & $\begin{array}{l}\text { HB: H96 (3.3), T199 }(2.8+3.0), \\
\mathrm{Zn}^{2+}(2.0) \\
\text { HC: L198, H94, V121, L141, F131, } \\
\text { P202, GOL } \\
\text { TCA: } 3428 \AA^{2}\end{array}$ & $\begin{array}{l}\text { HB: T199 }(3.0+2.8), \text { H96 (3.3), H94 } \\
\quad(3.3), \text { Q67 (wm), Zn }{ }^{2+}(2.0) \\
\text { HC: T200, L198, F131, V121, N62 } \\
\text { TCA: } 3449 \AA^{2}\end{array}$ \\
\hline
\end{tabular}

${ }^{\mathrm{a}}$ Numbering changed for consistency to CA II convention. For residues greater than 126 subtract 1 for the residue number in the $\mathrm{PDB}$

${ }^{b} \mathrm{HB}$ - hydrogen bond

${ }^{c} \mathrm{HC}$ - hydrophobic contact

${ }^{\mathrm{d}} \mathrm{TCA}$ - total contact area in $\AA^{2}$, as calculated by AreaIMol in CCP4i (3).

${ }^{\mathrm{e}} \mathrm{GOL}$ - glycerol present in active site

f $(w m)$ - water-mediated hydrogen bond 


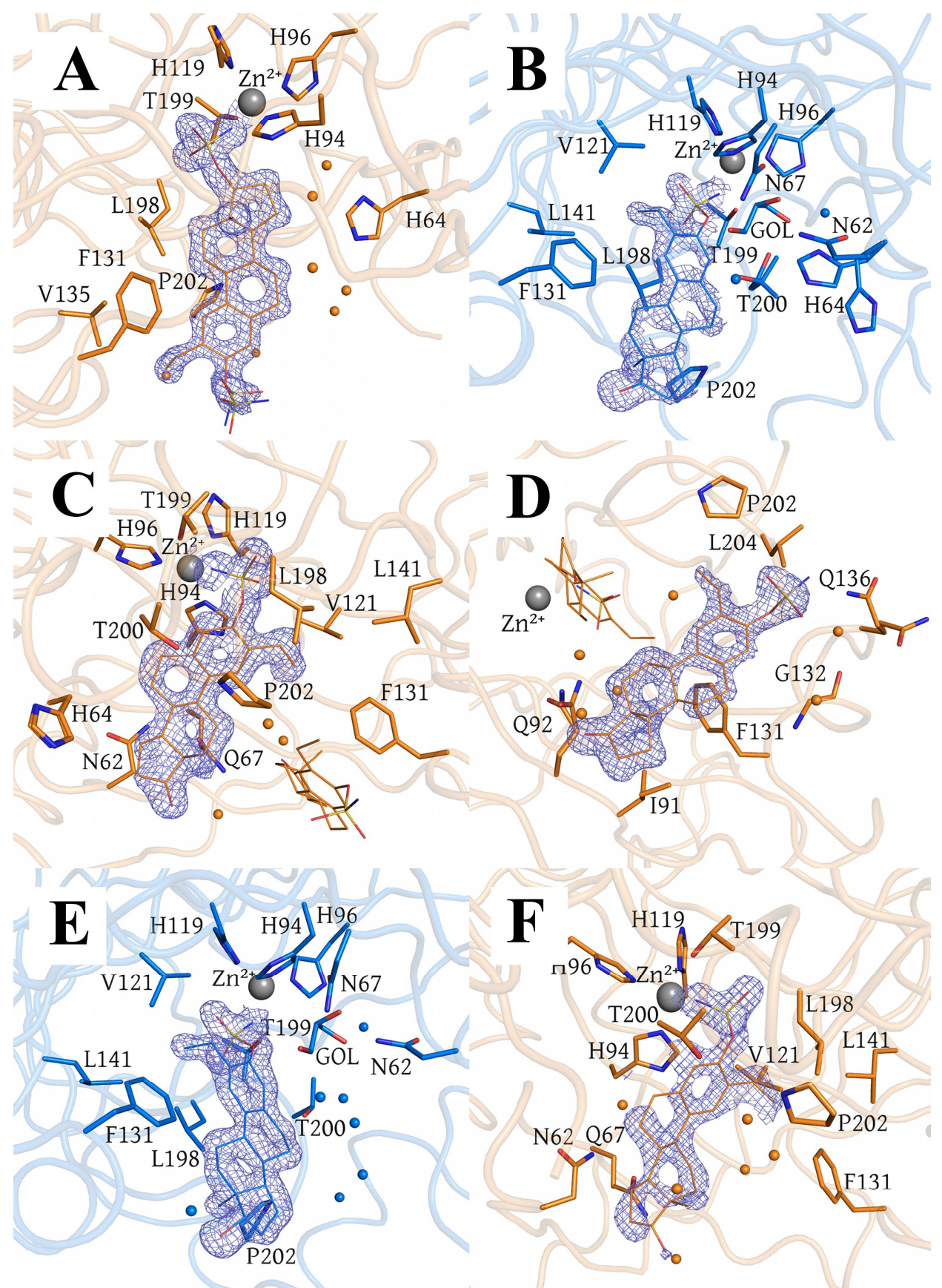

Supplemental Fig. 1. Electron density maps of compounds 14, 15, and 16. All maps are $2 \mathrm{~F}_{\mathrm{o}}-\mathrm{F}_{\mathrm{c}}$ averaged kick maps (4). Coloring is as follows: carbons from CA II complex, light blue; carbons from CA IX mimic complex, orange; oxygens, red; nitrogens, dark blue, sulfur gold. Zinc is represented by a large gray sphere. Small spheres colored the same as their respective carbons represent waters. (A) 14 complexed with CA IX mimic contoured to $1.2 \sigma$. (B) 15 complexed with CA II contoured to $0.8 \sigma$, (C) 15 molecule 1 complexed with CA IX mimic contoured to $0.8 \sigma$ (D) 15 molecule 2 complexed with CA IX mimic contoured to $0.8 \sigma$. (E) 16 complexed with CA II contoured to $1.0 \sigma$. (F) 16 complexed with CA IX mimic contoured to $1.0 \sigma$. Figure generated in Pymol (5). 


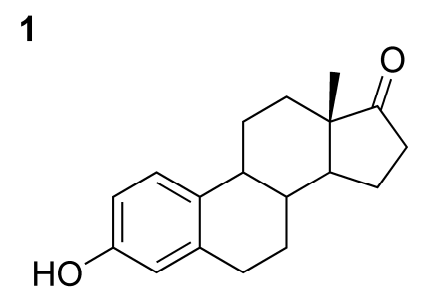

2<smiles>C[C@]12CCC3c4ccc(O)cc4CCC3C1CCC21OCCO1</smiles>

3<smiles>COCOc1ccc2c(c1)CCC1C2CC[C@]2(C)C1CCC21OCCO1</smiles>

4<smiles>CCc1cc2c(cc1OCOC)CCC1C2CC[C@]2(C)C1CCC21OCCO1</smiles>

5<smiles>CCc1cc2c(cc1O)CCC1C2CC[C@]2(C)C(=O)CCC12</smiles>

13<smiles>CCc1cc2c(cc1O)CCC1C2CC[C@]2(C)C1CC[C@@H]2O</smiles>

Supplemental Fig. 2: Chemical formulas of intermediate synthetic compounds. 


\section{Supplemental Reference}

1. Appel, R. D., Hochstrasser, D. F., Funk, M., Vargas, J. R., Pellegrini, C., Muller, A. F., and Scherrer, J. R. (1991) Electrophoresis 12, 722-735

2. Leese, M. P., Hejaz, H. A., Mahon, M. F., Newman, S. P., Purohit, A., Reed, M. J., and Potter, B. V. (2005) J Med Chem 48, 5243-5256

3. Potterton, E., Briggs, P., Turkenburg, M., and Dodson, E. (2003) Acta Crystallogr D 59, 1131 1137

4. Praaenikar, J., Afonine, P. V., Guncar, G., Adams, P. D., and Turk, D. (2009) Acta Crystallogr D Biol Crystallogr 65, 921-931

5. DeLano, W. L. (2002) The Pymol Molecular Graphics System. Delano Scientific, Palo Alto, CA, USA 